\title{
KERK, KROON EN CARIBEN
}

DOOR

\section{Cornelis Ch. Goslinga}

Het moge ons - twintigste eeuwers - een contradictie toeschijnen om het Evangelie te brengen op de punt van het zwaard, in andere eeuwen zag men deze tegenstelling niet of veel minder scherp. Van KAREL DE GROTE wordt reeds vermeld, dat hij de christelijke waarheden verkondigde met ijzeren tong; de Inquisitie meende in brandstapel en worging geoorloofde middelen te hebben om de zuiverheid van het geloof te handhaven en wanneer de gematigde BARTOLOMÉ DE OLMEDA de bekeringsijver van CORTÉs niet wat getemperd had, was ook bij de kerstening der. Azteken geweld het meest doorslaggevende argument geworden voor de verspreiding der Blijde Boodschap.

Bekering en onderwerping waren twee begrippen die én voor KAREL DE GROTE én voor HERnÁn CoRTÉs identiek waren en veelal voelden hun bekeerlingen zulks ook zo. Ter verontschuldiging van de grote ,,conquistador" van Mexico kan men misschien aanvoeren, dat hij in deze mening volkomen werd gesteund door de publieke opinie en, wat nog belangrijker is, door het toenmalige Spaanse Hof.

Immers, zodra Columbus van zijn eerste succesvolle reis naar de Nieuwe Wereld was teruggekomen en aan het Hof der Katholieke koningen de stoffelijke bewijzen had getoond van een rechtstreekser weg naar Indië dan die welke VASCO DA GAMA had ontdekt, deden zich voor IsABELLA twee kwesties op, voor welker oplossing zij zich gesteld zag. Deze beide kwesties waren die van de onderwerping der Indianen en die van hun bekering.

Bijna onmiddellijk sprong zij in de bres voor haar nieuwe onderdanen en stelde zij de Indiaan onder de bescherming van bepaalde wetten. Reeds in 1494 legde zij aan een commissie, bestaande uit theologen en juristen de vraag voor, of de Indiaan tot slaaf kon worden gemaakt. De voornaamste hof-jurist PALAcios Rubios pleitte voor vrijheid van de Indiaan en voor zijn 
recht op particulier bezit; gelijkertijd verkondigde hij echter de stelling, dat hij onbekwaam was zichzelf te regeren. Men bedenke bij deze wonderlijke uitspraak, dat dit werd gezegd in een tijd, toen alleen de vrij onbeschaafde Cariben waren ontdekt, terwijl de Maya's, Azteken en Inca's met hun goed georganiseerde regeersystemen nog geheel onbekend waren. Bij deze argumentatie legde een belangrijk gewicht in de schaal het verwijt van kannibalisme, dat de Spanjaarden echter vaak maar al te gretig uitten, wanneer zij op verzet stuitten.

De beroemde ontdekker Alexander von Humboldt, die twee eeuwen na de ontdekking Amerika doorkruist, schrijft ergens, dat de wanhopige moed, waarmede de Caribische Indianen zich verzetten tegen onderwerping aan de Spanjaarden, grotelijks had bijgedragen tot hun faam van wreedheid. Vele schrijvers erkennen, dat het verwijt van kannibalisme in sommige gevallen juist was. Ik behoef daarbij slechts de namen te noemen van ANtonio de Herrera, Bernardino de Sahagún, Gonzalo Fernández de Oviedo y Valdés, de Inca Garcilaso de la Vega, Bartolomé de las Casas, Francisco López de Gomara, Bernal díaz del Castillo en van vele anderen, tijdgenoten min of meer van de ontdekkers en veroveraars, om in hun werken talloze aanwijzingen te vinden voor de gerechtvaardigdheid van dit verwijt, al zullen in enkele gevallen wel die schrijvers eveneens gelijk hebben, die beweren dat het kannibalisme der Indianen een vergissing is, terug te brengen tot hun verzotheid op apenvlees.

Fray Pedro Simón, een der eerste schrijvers over de Venezolaanse Indianen en de beroemde Venezolaanse etnoloog LISANDRO ALVARADo zijn er intussen van overtuigd, dat voor de op het gebied van de tegenwoordige republiek Venezuela wonende Indianen kannibalisme een kwade gewoonte was, veelal op krijgsgevangenen toegepast. Volkomen in overeenstemming met die opvatting verklaarde de ,,justicia-mayor" van Española, RoDRIGO DE FIGUEROA, dat het alle christenen, i.c. alle Spanjaarden, want het pacte colonial liet nagenoeg geen vreemde infiltratie toe, vrijstond, de Cariben van de Islas de los Gigantes (Curaçao, Bonaire, Aruba), Margarita en de Tierra Firme gevangen te nemen en tot slaaf te maken, daar zij geen christenen doch kannibalen waren. Voor deze Indianen stonden dus slechts twee wegen open: de oorlog tot de dood of de dood in de mijnen of bij de veldarbeid onder het kerstenend toezicht van harteloze goudzoekers en avonturiers. Dat de Spanjaarden bij gebrek aan slaven - en dat gebrek ontstond bij de moordend zware arbeid vrij spoedig - maar al te graag strijd tegen de Indianen provoceerden, behoeft geen betoog. Soms werden zij hiertoe aangemoedigd door geestelijken, die het zwaard altijd nog een niet te versmaden werktuig achtten van de Heilige Geest en het heet zelfs, dat RODRIGo DE BASTIDES, 
bisschop van Venezuela, Puerto-Rico en Esspañola en zoon van de beroemde ontdekker, een zekere PEDRo DE Limpias heeft opgedragen om zoveel mogelijk Indianen uit de streek om Maracaibo gevangen te nemen en te verkopen aan de kooplieden van de Benedenwindse Eilanden, een handel die volgens een toenmalige kroniekschrijver ongeveer een halve eeuw heeft bestaan.

Het zou verkeerd zijn in deze opdracht van de bisschop onze twintigste eeuwse sentimenten te interpreteren. De waarschijnlijkste verklaringen voor deze ons zonderling aandoende raad is natuurlijk deze, dat de bisschop oprecht van mening was, dat het verlies der vrijheid niet telde bij de grote geestelijke winst: de kennismaking met de enig ware godsdienst en het eeuwig zieleheil, immers de meesters waren volgens koninklijk decreet verplicht de hun toevertrouwde slaven de beginselen der christelijke leer en der Katholieke liturgie bij te brengen. Want het eeuwig heil der Indianen ging Kerk en Kroon zeer ter harte; daartegen viel het gering geachte stoffelijk nadeel als het verlies der vrijheid volkomen in het niet.

Aan deze opmerking moet onmiddellijk worden vastgeknoopt, dat evenals onderwerping en bekering begrippen waren die vrijwel identiek gerekend werden te zijn, voor Spaans Amerika ook Kerk en Kroon twee machten waren, die voor een groot gedeelte samenvielen, daar immers de Spaanse Kroon bijna complete volmachten had over de Kerk. Zo althans drukt Solorzano Pereira zich uit, die de toeneming van de invloed van de Kroon op de Kerk gedurende de zestiende en zeventiende eeuw aan een nauwkeurige studie heeft onderworpen.

Twee onverstandige pauselijke bullen ${ }^{1}$ ), ,,Inter Caetera" en ,Eximae devotionis", beide in 1493 uitgevaardigd, leverden de Nieuwe Wereld in de macht der Katholieke koningen, wier enige tegenprestatie die van kerstening was. Geen geestelijke kon voet aan land zetten in het nieuwe werelddeel zonder toestemming van de Koning. Alle pauselijke mededelingen moesten ter goedkeuring aan de Kroon worden voorgelegd en indien de koninklijke sanctie werd geweigerd, werd dit weliswaar de Curie medegedeeld doch er werd geen uitleg gegeven. Zelfs de kerkelijke tienden werden door de Kroon geïnd, aanvankelijk althans. Een derde bul van 1508, ,Universalis Ecclesiae”, maakte de greep van de Kroon op de Kerk in Amerika nog steviger door het toelichten van duistere of dubbelzinnige passages in de beide voorafgaande.

Men kan niet zeggen, in het algemeen gesproken, dat de Spaanse koningen deze vergaande rechten hebben misbruikt. De toch wel als geslaagd te beschouwen kolonisatie en kerstening van Latijns Amerika is daarvoor een niet te miskennen bewijs. $Z_{i j}$ benoemden godvruchtige en bekwame bisschoppen, al verlieze men daarbij natuurlijk nooit uit het oog, dat deze

1) Onverstandig in die zin, dat het nimmer in het belang kan zijn van de Kerk, wanneer deze prerogatieven delegeert aan de Kroon d.i. aan de wereldlijke macht.

West-Indische Gids XXXVI 
mannen in overgrote meerderheid kinderen van hun tijd waren, behept met alle vooroordelen die hun eeuw aankleefden. En al was dan de pauselijke invloed in feite niet zo groot, in naam bleef de Heilige Vader in Rome natuurlijk het Hoofd der Kerk, wie men gehoorzaamheid schuldig was.

Ondanks de ruime delegatie van hun macht aan de Spaanse Kroon, trachtten de Pausen toch dikwijls ten gunste van de Indianen op te treden. PAUlus III verklaarde hen in een bul van 1537 tot redelijke wezens, in staat om de beginselen van het $\mathrm{Ka}$ tholieke geloof te leren en te belijden, zodat zij dus recht hadden op de weldaden van dat geloof. $\mathrm{Zij}$, die de Indianen plunderen of beroofden van hun bezittingen werden met excommunicatie bedreigd.

De katholieke IsABELLA, wier bemoeienis met haar nieuwe onderdanen zulk een flagrante tegenstelling vormt met de duidelijke onverschilligheid die haar kleinzoon KAREL V aan de dag legt voor alles wat buiten de Europese aangelegenheden viel, en voor wie onderwerping en bekering hetzelfde betekenden, maakte, gesteund door een aantal pauselijke bullen van ALEXANDER VI, die om het zo maar eens uit te drukken wereldlijk gesanctionneerd waren door het beroemde verdrag van Tordesillas, ernst met beide zaken. Toen Columbus haar hoge toestemming vroeg om de Indianen te dwingen tot het verrichten van werkzaamheden voor de Spanjaarden - in feite waren zij reeds gedwongen en probeerde de Admiraal een bepaalde toestand te legaliseren - zocht de Kroon nog een uitweg om de Indianen als vrije onderdanen te behandelen en bekend is de vraag van IsABELLA, toen haar werd medegedeeld, dat Columbus 300 Indianen onder de Spanjaarden als slaaf had verdeeld: „¿Con qué autoridad dispone el Almirante de mis vasallos?" [Krachtens welke autoriteit beschikt de Admiraal over mijn vazallen?] In 1503 werden de Indianen door een koninklijk decreet vrij verklaard, doch tegenstrijdig genoeg werd tevens toestemming gegeven om hen te dwingen tot werk in de mijnen of op het veld. Met deze koninklijke order deed de ,encomienda" haar intrede in Spaans Amerika.

De ,encomienda”, een begrip dat niet in geheel Spaans Amerika precies hetzelfde aanduidt en die met name in Nieuw Spanje zich andere heeft ontwikkeld als in het Caribisch bekken, is in het algemeen het in ,,herendienst" brengen van Indianen onder Spaanse meesters, die als ,,encomenderos" fungeerden en daarenboven nog het recht hadden, schatting van hun verkapte slaven te eisen. Als tegensprestatie, merkten wij reeds op, was de encomendero verplicht de aan zijn zorg toevertrouwde slaven in de Katholieke geloofswaarheden te onderwijzen en bovendien moest hij hen nog beschermen. 
Opgemerkt moet worden, dat als ,,feudaal" instituut de ,encomienda." natuurlijk regelrecht inging tegen de belangen van de Kroon, die de macht zoveel mogelijk in eigen handen wilde concentreren. Zeker inspireerde ook deze overweging het besluit van KAREL V in 1542 om de ,encomienda" op te heffen. Deze maatregel verwekte echter grote ontevredenheid (van de meesters) terwijl zelfs oproerige bewegingen ontstonden. De Kroon kon alleen erger voorkomen door de uitvoering dezer „Nuevas Leyes” op te schorten en later de wetten geheel in te trekken. Van het ene kwaad kwam het andere, terwijl nog tot 1536 de ,,encomienda" erfelijk was voor één generatie, werd ze dat op de duur voor vijf.

Tegen dit systeem van verkapte slavernij verhieven zich natuurlijk stemmen en de rij van mannen, die er tegen protesteerden is waarlijk indrukwekkend. Nicolas DE OBANDA, de derde gouverneur van Española, was misschien de eerste die tegen de „,encomienda" ageerde en de belangen van de Indiaan verdedigde, doch zijn goedbedoelde pogingen leden schipbreuk door het koninklijk decreet van 1503. Machtiger in het koor van hen die zich als kampioen opwierpen voor de Indianen, werd de stem van enige geestelijken, doch eer deze stem gehoord werd, waren reeds twee decennia verlopen van onbeteugelde exploitatie.

Eén der eerste geestelijken die tegen de grenzeloze uitbuiting, verslaving en wreedheid zijn stem verhief was fray ANTONIO DE Montesinos. Zijn eerste protest draagt de welsprekende en alleszins duidelijke titel: „Ego vox clamantis in deserto”, doch schoot haar doel door haar heftigheid voorbij. De bevolking van de stad Santo Domingo protesteerde bij de gouverneur - de Spaanse bevolking wel te verstaan - en deze dreigde na ontvangen orders uit Spanje van Ferdinand (in 1512) om de ,,brutale” Dominicaan naar Spanje te zenden als hij zijn mond niet hield. Ook de superieur der Dominicanen in het Moederland legde MoNTESINOS een spreekverbod op onder de vreemde bedreiging anders geen paters meer naar Española te zullen zenden, wanneer dergelijke schaamteloze predicaties voortduurden. Onder degenen, die zich over het optreden van Montesinos bij de gouverneur beklaagden, bevond zich ook de door herendiensten in Española schatrijk geworden BARTolomé dE las CASAS. Deze, hoewel hij de priestergelofte reeds in 1510 had afgelegd, nam kort daarop zelfs nog deel aan de verovering van Cuba.

De kwestie kwam toch in Spanje en MonTesinos ging zelfs naar het Moederland om zijn zienswijze te verdedigen. FERDINAND kwam daarbij zo onder de indruk van de gruwelijke uitbuitingen en onbeteugelde hartstochten der Spanjaarden, door MoNTEsinos in de welsprekendste bewoordingen beschilderd, dat hij een 
commissie benoemde om uitspraak te doen. In deze commissie trachtten sommige leden met behulp van uitspraken van Aristoteles, Tomas van Aquino, Duns Scotus en Augustinus van Ancona te bewijzen, dat de Indianen van nature tot slavernij waren voorbeschikt. Doch zo sterk sloeg tenslotte de schaal niet in het nadeel van de Indiaan over en men kwam met voorstellen als eindconclusie voor de dag die de basis zouden vormen voor de beroemde wetten van Burgos, die in 1512 werden afgekondigd. Deze wetten vertegenwoordigden zo volkomen mogelijk de opvatting van de Kroon over de ideale verhouding van Spaanse koning en Indiaanse vazal en beschreef ook de rechten en plichten van Spanjaarden en Indianen onderling. Wanneer het woord niet te anachronistisch klonk, zou men in hen een soort constitutie kunnen zien voor Latijns-Amerika die enige eeuwen van kracht is geweest.

Schone bepalingen worden gegeven, waaraan de Spanjaard zich te houden heeft. Al gaan de wetten van Burgos uit van de,,encomienda" als basis der maatschappelijke structuur, zo wordt toch wel streng omschreven, wat de inhoud van dit begrip precies is. De ,encomendero" moest b.v. voor zijn ,,encomendados” huizen beschikbaar stellen, waarin zij konden wonen, hij moest hun voldoende voedsel verstrekken, op alle 50 Indianen moesten 12 kippen en een haan zijn. Hun geestelijk heil had vanzelfsprekend eveneens de zorg der overheid: er moesten kerken worden gebouwd en methodes werden aangegeven om de heidense Indiaan tot bekering te brengen. Wie meer dan 50 Indianen onder zich had, moest er één leren lezen en schrijven, zodat die als onderwijzer voor de anderen kon fungeren en elke begrafenis moest plaats vinden onder het teken des Kruises. De meesters moesten er bovendien strengelijk op letten, dat de pasgeborenen binnen 8 dagen werden gedoopt. De zoons der ,,caciques" of opperhoofden - de toekomstige Indianenhoofden dus - moesten op 13-jarige leeftijd gedurende vier jaren onder de hoede der Franciscanen verblijven, opdat zij zouden worden onderwezen in het geloof, in lezen en schrijven en in de Latijnse grammatica. Bovendien - al werd dit niet met zoveel woorden gezegd - kon men dan die jongens in de meest impressionabele leeftijd tot goede vazallen van de Kroon vormen.

Straffen werden vastgesteld voor wie de Indianen lasten oplegde, daar in 1512 de lastdieren, uit Spanje aangevoerd, zich reeds voldoende hadden vermenigvuldigd. Wel mocht men de Indiaan voor veld en mijnarbeid gebruiken, waarbij de hoeveelheid voedsel die hem verstrekt moest worden, nauwkeurig was vastgesteld. $\mathrm{Z}_{\mathrm{ij}}$ die in de mijnen werkten, mochten niet langer dan vijf maanden per jaar werken, hadden dan recht op 40 verlofdagen, en konden dan voor velddiensten worden gebezigd. Zwangere vrouwen mochten niet werken. Het uitlenen van ,encomendados" was streng verboden, tuchtiging met de zweep of met een stuk hout eveneens. Speciaal benoemde inspecteurs moesten toezicht houden op de stricte naleving dezer voorschriften. Een half jaar later werden deze wetten nog aangevuld door die van Valladolid, waarin speciaal het werk en de werktijden van gehuwde vrouwen en onvolwassenen wordt gereglementeerd. 
Toen het Hof op de hoogte kwam van de behandeling de Indianen aangedaan, beschikte het, dat zij moesten worden beschouwd „,como los demas vasallos" [als de overige vazallen]. Tegelijkertijd stond het echter toe, dat diegenen die zich verzetten tegen de Spaanse heerschappij in slavernij mochten worden gehouden. Reeds wees ik er op, dat deze bepaling met gretigheid werd toegepast - en dan natuurlijk in ruime zin - waar men werkkrachten nodig had. Bovendien waren de Cariben in de streken van de Orinoco eigenlijk nooit goed gepacificeerd - volgens getuigenissen van toenmalige schrijvers waren zij kannibalen, een beschuldiging die maar al te gaarne werd uitgebreid ook over vredelievende stammen. De voornaamste reden van al deze ontduikingen van in zichzelf goede wetten, was de verre afstand tot Spanje, waardoor de arm van de Koning dikwijls niet ver genoeg reikte om misbruiken te straffen, terwijl evenmin alle bepalingen niet even gemakkelijk konden worden uitgevoerd.

De slechte behandeling die de Indianen in de mijnen of bij de veldarbeid ondergingen deed hen bij honderden sterven en was niet bepaald bevorderlijk voor een vruchtbare bekering. Steeds nieuwe slachtoffers moesten worden geworven, geroofd en gevangen om het werk gaande te houden. Officieel moesten bekendmakingen, de z.g. ,,requerimientos" de Indianen mededelen, wiens vazallen zij waren, dat zij zich moesten onderwerpen, daar zij anders tot slaaf zouden worden gemaakt en dat er één God was in de Hemel en één Paus op aarde die hun land in naam van die God aan de Spaanse koningen had geschonken. Zo de Indianen deze mededelingen al begrepen, zullen zij vermoedelijk niet hebben gezien welk verschil er bestond in het gedwongen werk dat zij moesten verrichten die zich vrijwillig onderwierpen,en de slavenarbeid die de in de strijd gevangen Indianen werd opgedragen.

Doch aan de kust van Cumaná hadden de requerimientos aanvankelijk succes. Talloze gevangenen werden gemaakt en daar de Spanjaarden tenslotte ook niet meer het verschil zagen tussen de vrijwillige herendienstplichtigen en de tot slavenarbeid gedwongen gevangenen, of voor dit subtiele verschil een oogje dichtknepen, werd het overschot van de werknemers, om met deze moderne term het totaal der ongelukkigen aan te duiden, maar op schepen geladen, en voor vervoer naar Curaçao of Cuba bestemd. Meestal werden zij daarbij met een $\mathrm{C}$ in het gelaat of op de ledematen gebrandmerkt. Reeds in de Spaanse tijd zijn dergelijke slavenladingen op Curaçao aangekomen, dat echter vooral als doorvoerhaven fungeerde. De bekendste Indianenjagers - het Spaans heeft er zelfs een apart woord voor: , indieros" - zijn Alonso DE OJEDA (niet de ontdekker van Curaçao doch een naamgenoot), Diego de Ordaz en Gerónimo de Hortal.

En tòch, ondanks deze misdadige praktijken, discussieerde men gemoedelijk door over de belering van de Indiaan. Hoe lang moest hij worden onderwezen, alvorens gedoopt te kunnen wor- 
den? Hadden de pas-bekeerden recht op alle sacramenten? Moest de Inquisitie de ketterij onder de Indianen bestrijden of hen voorlopig maar met rust laten wegens hun onbeschaafdheid en onbekwaamheid tot onderscheid? Waren de martelingen geoorloofd, die fray DIEGo DE LANDA sommige heidense Indianen in Yucatán had doen ondergaan? Moesten de Indiaanse kinderen het kerklatijn leren?

Hoe wonderlijk deze zaken, schrijft HaNke in zijn boeiend werk The Struggle for Justice in the Spanish Conquest of America, de moderne lezer ook mogen voorkomen, het feit blijft bestaan dat zij heftig werden besproken gedurende de gehele 16e eeuw. Sommige geestelijken verdedigden in hun expansie-gezindheid de massadoop der Indianen, waarover PRESCOTT ons een vermakelijk staaltje geeft in zijn Conquest of Mexico; anderen wilden echter eerst, dat zij enig begrip voor de beginselen der nieuwe leer zouden tonen. LAS CASAS stelt in zijn werk Apologética Historia de las Indias de Indianen in vele opzichten boven de Spanjaarden, waarbij dan veelal de avonturiers en goudzoekers worden bedoeld, die naar de Nieuwe Wereld getrokken waren om allerlei materiële en egoistische motieven en voorzeker niet de beste specimina van de soort waren. Andere kampioenen der Indianen, realistischer dan de warmbloedige BARTOLOMÉ, nemen toch vrijwel een gelijk standpunt in. $\mathrm{Zij}$ vonden natuurlijk bij hun verdediging van de Indiaan een geweldige steun in twee grondslagen van het christendom: dat alle mensen voor God gelijk zijn ongeacht kleur, ras en ontwikkeling, en dat de Christen verantwoordelijk is voor zijn naaste, waarbij diens geestelijk en zedelijk peil er niet toe doet. Het strekt tot eeuwige eer van Spanje, dat deze zienswijze het op de lange duur gewonnen heeft.

Daarbij bedenke men, dat de avonturiers, de goudzoekers en de gelukzoekers toch vaak onder de ijzeren vuist van een groot man in de bedding werden gedreven van een voortdurende strijd onder de vaan van het Kruis, of zij wilden of niet. Vele grote conquistadores, Herná Cortés vooraan en zonder daarbij voorbij te zien hun grote misslagen, misdaden desnoods, mogen wij, op grond van wat zij hebben geschreven, met het volste recht beschouwen als soldaten van de Kerk in de grote strijd voor de uitbreiding van het christelijk geloof. Wanneer CoRTÉs ergens schrijft: „,Daar wij de banier van het Kruis dragen en vochten voor ons Geloof en voor Uwe Majesteit gaf God ons zodanige overwinning, dat wij tallozen doodden, zonder dat de onze gewond werden", dan is hij zelf ten volle overtuigd van de waarheid dezer woorden en in meer dan één opzicht kan men de verovering van de Nieuwe Wereld Spaanse kruistochten noemen onder het magisch woord: God wil het.

Drie jaar na het eerste geluid, dat Montesinos ten gunste van 
de Indiaan horen deed, trad BARTolomé DE LAS CASAS op als hun grote voorvechter. Ten opzichte van de Indianen nam hij, zoals wij reeds opmerkten, aanvankelijk geen uitzonderlijke houding aan, door hun zweet en tranen was hij rijk geworden. Toen hem echter wegens zijn onchristelijke behandeling der hem toevertrouwde ,encomendados " door een Dominicaans priester de absolutie geweigerd werd, kwam hij tot nadenken. Weldra zag hij met verontwaardiging de ellende en misdaad, waaraan de Indiaan dagelijks blootgesteld stond en hij ging daarom naar Spanje om daar de Indiaanse zaak aan het Hof te bepleiten. FERDINAND stierf kort nadat LAS CASAS in Spanje was aangekomen en de jonge KAREL was nog niet aanwezig. Kardinaal XIMÉnEZ voerde echter in diens naam met straffe hand het bewind. Hij luisterde naar de klachten van LAS CASAS en benoemde op staande voet een commissie van drie geestelijken om de misbruiken weg te nemen. LAS CASAS kreeg de schoone titel: Beschermer van de Indianen.

Het is hier niet de plaats om al te uitvoerig in te gaan op de maatregelen die deze commissie voorstelde. LAS CASAS, terug in West Indië en door ongeduld verteerd, lag weldra overhoop met de voorzichtigheid waarmede veranderingen en hervormingen werden voorgesteld. Weer ging hij naar Spanje, dat hij nu onder Vlaams regiem vindt. Toch werden de Amerikaanse aangelegenheden niet zo verwaarloosd als de vurige kampioen zich had voorgesteld, al moeten wij toegeven, dat KAREL zelf nooit veel interesse betoond heeft en zoveel mogelijk overliet aan de Raad van Indië en het Casa de Contratación. De raad van Indië had een soort memoriaal gekregen, een heftig protest tegen het systeem der encomiendas van de hand van een Dominicaan, MiguEL DE Salamanca. Zij had dit niet slechts met Spaanse hoffelijkheid aanvaard, doch er ook ernstig onderwerp van discussie van gemaakt, met het gevolg, dat de koning in Mei 1520, toen hij weer eens in het land was, decreteerde, dat de Indianen vrij waren, een herhaling alzo van het besluit van IsABELLA dat in feite neerkwam op opheffing der wrede ,repartimientos" of verdeling der Indianen onder de Spanjaarden, iets waarover Columbus al een uitbrander had gekregen van zijn koningin. Of dit bevel van $\mathrm{KA}_{\mathrm{A}}$ REL echter veel effect sorteerde, staat te bezien.

LAS CASAS, even heftig als DE SALAmanca, verdedigde in een vergadering van de Raad van Indië onder presidium van de jonge koning eveneens op felle wijze de zaak der Indianen. In een twistgesprek met bisschop JUAN DE QUEREDO liet hij duidelijk blijken, enige lustra vóór de officiële pauselijke bevestiging, dat hij over- 
tuigd was van de redelijke aard van de Indiaan en het gloedvol betogen van de vurige Dominicaan bewerkte, dat KAREL, hoewel in grote haast daar hij naar Worms moest, waar hij LUTHER in de ban zou doen, zijn voorlopige goedkeuring hechtte aan een plan, dat LAS CASAS de Raad van Indië ter onderzoek had voorgelegd, nl. dat van kolonisatie van de Noordkust van Venezuela door Spaanse landarbeiders.

Dit plan zou het systeem der ,,encomienda” met zijn gruwelijke uitbuiting overbodig maken en moet dus gezien worden als een eerste practische poging om de ondraaglijke toestand, waarin de Indianen reeds in de twintiger jaren waren geraakt, te verbeteren. Vanzelfsprekend kwam dit plan maar niet zo uit de lucht vallen: het had een soort van voorloper in een door LAS CASAS opgesteld proyect van enige jaren te voren dat duidelijk geinspireerd was op de Utopia van Morus (1518). Het gaf een aantal manieren aan om de Indianen tot zelfbestuur op te voeden en ging bijgevolg van de redelijkheid der Indianen uit.

Deze kolonisatiepoging werd een volkomen en vernederende mislukking, hoewel LAS CASAS in zijn voorstellen tot de koning de Tierra Firme noemde ,la mejor tierra y más rica que de ella ahora se sabe" [De beste en rijkste grond, die men tot nu toe kent] en ondanks het feit, dat in het decreet van de koning, waarin deze poging werd gesanctionneerd en waarbij de Vlaamse raadgevers van de Ǩnoning hun goedkeuring had̉den gegeven, aan de toekomstige kolonisten in Venezuela bepaalde voorrechten werden gegarandeerd. De moeilijkheden die de edele priester bij zijn werving van landarbeiders voor de Nieuwe Wereld door geheei Spanje ondervond, de tegenwerking, de smaad en laster die hem daarbij ten deel vielen, zouden vele bladzijden kunnen vullen. Nog vóór LAS CASAS, door alle tegenwerking, een voldoend aantal toekomstige kolonisten had verzameld, zeilde een zekere kapitein BERRIO met een vijftigtal families, totaal 207 personen volgens LAS CASAS ,la hez de la tierra" [het uitvaagsel van de maatschappij] - met steun van de Casa de Contratación van Sevilla naar de Nieuwe Wereld om LAS CASAS voor te zijn. In Española ging die expeditie te gronde. Doch dit had weer het ongelukkige gevolg, dat de koning en zijn raadgevers tot de conclusie kwamen, dat kolonisatie niet mogelijk was. LAS CASAS zette echter door en tenslotte gaf KAREL V toch weer toe. De concessie werd verleend.

Het was voorwaar geen geringe taak, die de hartstochtelijke monnik zich gesteld had: de vestiging van Spaanse kolonisten op de $1000 \mathrm{mijl}$ lange kust van Venezuela. Tot dat doel stichtte hij zelfs een soort van 
orde, die der Caballeros de la Espuela Dorada [Ridders van de Gouden Spoor]. Wij merkten reeds op, dat het hem aan tegenstand niet ontbrak. Twee zijner hardnekkigste antagonisten waren bisschoppen: JUAN DE Quevada, bisschop van Tierra Firme en die oude vijand van Columbus, JuAn Rodrfiguez de Fonseca, bisschop van Burgos, volgens PrescotT "quick to take offense and slow to forgive" een gevaarlijk en hardnekkig tegenstander.

Met steun van Diego Colón, zoon van de Admiraal, gelukte het LAS CASAS eindelijk alle hinderpalen weg te werken. In November 1520 zeilde hij uit Sanlucár met 70 uitgezochte arbeiders In Februari 1521 kwam hij in Puerto Rico aan.

Hier vernam hij dat de Cariben van Chiribichi en Maracapana, aan de Tierra Firme, een aantal priesters, die daar nederzettingen hadden gesticht, gedood hadden en dat de Audiencia van Santo Domingo - daar ressorteerde Venezuela grotendeels onder bezig was een soort strafexpeditie uit te rusten, teneinde de Indianen te straffen en - onder dit prachtig voorwendsel - tevens tot slaaf te maken. LAS CASAS stelde alles in het werk om het uitvaren van deze expeditie te verhinderen. Hij wees er op, dat het gebeurde met de Dominicaanse priesters een gevolg was van de strooptochten van ALonso de OJEDA (niet de ontdekker) en bereikte tenslotte, dat hij mee zou gaan naar de genoemde nederzettingen. Wanneer hij dan zelf zou hebben geconstateerd, dat de betrokken Indianen kannibalen waren, zou er worden gevochten. Toen las CaSas met dit resultaat terug kwam op Puerto Rico wachtte hem echter een bittere teleurstelling: zijn ,,humildes e industriosos labradores" [nederige en ijverige landarbeiders] waren allemaal gedeserteerd naar de Spaanse goudzoekers en avonturiers aldaar om gezamenlijk de Cariben aan te vallen en te beroven.

Toch ging hij naar de Tierra Firme om daar nog te redden wat te redden viel. Een Spaans kapitein, Gonzalo DE OcAmpo, besteedde er zijn tijd met het vangen, kastijden en tot slaaf maken van talloze Indianen en stoorde zich geenszins aan LAS CASAS. Deze ging daarop naar Cumaná, waar de Franciscanen reeds in 1516 een klooster hadden gebouwd - het eerste in Venezuela - doch hij kon er niets uitrichten. De nederzetting werd voortdurend aangevallen door Cariben die dronken waren door de wijn, die Spaanse avonturiers ruilden voor goud. De Franciscanen bewogen LAS CASAS om terug te gaan naar Santo Domingo om bij de Audiencia zijn klachten te formuleren tegen deze misdadige handel. Tijdens zijn afwezigheid vielen de Indianen opnieuw het klooster aan en verbrandden het. De meeste kloosterlingen wisten 
gelukkig te ontsnappen en ook de kleine Spaanse bezetting onder FRANCISCO DE SOTO scheepte zich ongedeerd in. LAS CASAS, na een emotievolle reis eindelijk in Santo Domingo aangekomen, was door de loop der gebeurtenissen en door de mislukking van zijn groots plan zodanig getroffen, dat hij het klooster inging en 16 jaar aldaar het habijt droeg der Predikheren.

Toch gaf hij nimmer zijn plan geheel op. Later wist hij het tot werkelijkheid te brengen in Guatemala en bewees hij, hoe juist de beginselen waren, waarop hij zijn edele pogingen had gebaseerd. Ook de prachtige resultaten, die de Jezuieten behaalden in de $17 \mathrm{e}$ en $18 \mathrm{e}$ eeuw in Paraguay, langs geheel vredelievende weg, bewijzen de juistheid van LAS CASAS' grootse visie. Doch evenals zovelen, die hun tijd vooruit zijn, was ook LAS CASAS door verkeerd begrip omringd. Bekering langs vredelievende weg door kolonisatie was een ongehoorde tesis, die niet dan na vele jaren langzamerhand tot erkenning kwam. En tegen de achtergrond van een halve eeuw van bloedige verovering, van haat en verachting voor de Indiaan, schreef LAS CASAS zijn verhandeling: Del único modo de atraer a todos los pueblos a la verdadera religión. [Over de enige wijze om alle volken te trekken tot de ware religie.]

Dat in Spanje op de lange duur meer belangstelling begon te ontwaken voor dat facot, dat de Nieuwe Wereld bood. kon LAS CASAS alleen maar verheugen. Hij was er bovendien de man niet naar om de aandacht hiervoor te doen verslappen, want tot op hoge leeftijd - hij werd 92 jaar - ging hij voort met de Indiaanse zaak bij het Hof te bepleiten. Schokkende onthullingen over de behandeling der Indianen deden zijn zaak alleen maar goed: het geheime onderzoek tegen de onderkoning AnTonio DE MENDOZA bracht ontstellende toestanden aan het licht; het werk van pater Motolinia Historia de los Indios de la Nueva España gaf opzienbarende bijzonderheden, de wreedheden van PEDRO DE VALDIviA schenen nauwelijks geloofwaardig en werden toch door bewijzen gestaafd. Voor Venezuela en de Costa Firme ontbreken dergelijke schokkende getuigenissen; dat de toestanden daar veel beter waren, moet echter ten zeerste worden betwijfeld.

Grote voldoening moet het hem dan ook hebben gegeven, dat mede onder de indruk van een overstelpend feitenmateriaal aan misbruiken en uitspattingen ten opzichte van de Indiaan, KAREL $\mathrm{V}$ overging tot de opzienbarende maatregel, die ik in het begin van dit opstel reeds noemde: de opheffing van de wetten van Burgos door de Nieuwe Wetten, het laatste van een reeks van experimenten van Spanje op het gebied van Amerikaanse wet- 
geving en een mislukt experiment. Want het opheffen van de „,encomienda" was niet meer mogelijk, te zeer was zij reeds verweven in de maatschappelijke structuur der Nieuwe Wereld.

Ik weet niet, of behalve door LAS CASAS KAREL V ook nog is beinvloed geweest door bisschop Sebastín Ramfrez de Fuenleal van Santo Domingo, een verklaard tegenstander van het systeem der encomienda. Een aantal wijzigingen, door hem voorgesteld, werden door de Kroon verworpen, al schreef KAREL aan de Virrey (onderkoning, er was er toen nog maar één, nl. die van Santo Domingo) dat hij moest toezien, of de ,encomenderos" hun ,encomendados" wel onderwezen in de beginselen der Christelijke leer; ook zij, die als slaaf in de mijnen en op het land moesten werken, hadden recht op dit onderwijs en wie dit trachtte te verhinderen, moest worden gestraft.

In 1546 herroept KAREL V zijn maatregelen van 1542. Vanaf dat moment, wanneer dus de ,encomienda" met de verderfelijke „,repartimientos” officieel erkend wordt door de kleinzoon van haar, die vol verontwaardiging elke aanspraak van rechten op haar Indiaanse vazallen van de hand had gewezen, begint eerst recht de lijdensgeschiedenis van de Indiaan in Spaans Amerika. Het doet er weinig toe, of men al opmerkt, dat LAS CASAS voorstelde de door kardinaal CisNERos gesuspendeerde import van negerslaven te herstellen om daardoor het lot van de Indiaanse slaaf te verlichten. Diens positie werd niet noemenswaard beter, zijn uitbuiting en afwerking gingen door en werden gecomplementeerd door een nieuwe misdaad: die aan het negerras gepleegd. Dat LAS CASAS dit niet bedoeld heeft en dit niet heeft voorzien, spreekt vanzelf.

Indrukwekkend is de latere unanimiteit der geestelijkheid in haar appreciatie van de herroeping der ,Nuevas Leyes” en van de wederinvoering der wetten van Burgos. Het is moeilijk uit te maken of dit kwam, doordat de Kerk reeds grootgrondbezitster was geworden en daardoor economische belangen had bij het stelsel, dat zo verderfelijk was voor één bepaalde laag der bevolking. Zeker waren er priesters die, hoewel zij zich beschermers der Indianen noemden, in werkelijkheid hun onderdrukkers waren. Dat zij misschien uit innerlijke overtuiging de Indiaan geen redelijk en zedelijk wezen achtten doet daar weinig aan toe en af. Een feit is, dat de Indiaan, die onder de bescherming der missie kwam, zijn natuurlijke levendigheid en levenslust verloor - dit beweert de ter zake kundige Alexander von Humboldt - en het indolente en trage schepsel werd, dat voor weinig of geen ontwikkeling vatbaar bleek.

Het is rechtvaardig te erkennen, dat de vredelievende bekering der Indianen door de religieuze orden oneindig veel goed heeft gedaan. Het is rechtvaardig er op te wijzen, dat deze orden steeds de zaak van de Indiaan bij de Kroon hebben bepleit. $\mathrm{Zij}$ hebben zich steeds verzet tegen de excessen der encomenderos, tegen hun wreedheden, hun bloedvergieten. 
Maar wanneer eenmaal de fundamenten van bekering en onderwerping aan de regels ener beschaafde samenleving waren gelegd, werd hun bestuur vaak schadelijk zowel voor de ontwikkeling der gemeenschap, als wel voor de vooruitgang van het individu.

De opheffing van de Nieuwe Wetten in 1542 was niet een totale liquidatie van een bepaalde politiek. De paragrafen tegen de wreedheden die de Indianen tot slachtoffer dreigden te maken der ,,encomenderos" werden nimmer herroepen; ook die artikelen die de persoonlijke diensten afschaften bleven gehandhaafd. Doch dat zij herhaaldelijk werden geratificeerd, impliceert natuurlijk dat zij nog vaker werden overtreden.

GIL ForToul, schrijver van een driedelige Historia Constitucional de Venezuela, maakt nog speciaal melding van een koninklijke wet (van 1697) die nog weer eens de aandacht vestigt op de goede behandeling, bescherming, verdediging en bekering der Indianen en van een nieuwe groep, die de autochthone weldra in aantal zal overtreffen: die der mestiezen. Deze laatste groep, die blanke en Indiaanse karaktertrekken op vaak gelukkige wijze verenigde, heeft zich uiteindelijk niet neergelegd bij de politiek van Kerk en Kroon inzake onderwerping en bekering. Van deze groep zal de revolutie uitgaan, die de politieke en economische macht van Kerk en Kioun wegraagde.

\section{LITERATUUR}

Acosta Saignes, Miguel: Los Caribes de la Costa Venezolana, Caracas 1946.

Alvarado, Lisandro: Datos etnográficos de Venezuela, Caracas 1945, 2a. ed.

Baralt, R. M. \& Dinz, R.: Resúmen de la Historia de Venesuela, Brujas 1939, 2a. ed.

Brion, MARCel: Bartolomé de las Casas, „Father of the Indians", New York 1929.

CAsAs, BArtolomé de las: Historia de las Indias, Barcelona 1929, 3 tomos.

DIFFIE, BAILEY W.: Latin A merican Civilization, Harrisburg Pa. 1947, 2nd. ed.

GiL Fortoul, J.: Historia Constitucional de Venezuela, Caracas 1942, 3a. ed.

HANKE, Lewis: The Struggle for Justice in the Spanish Conquest of America, New York 1949.

Haring, Clarence: Buccaneers in the West-Indies, New York 1910.

Humbold, A. von: Viaje a las Regiones equinocciales del Nuevo Continente, Caracas 1941,5 tomos.

Kirkpatrick, F. A.: The Spanish Conquistadores, London 1934.

MAderIAgA, SAlvAdOR DE: The Rise of the Spanish A merican Empire, New York 1947. MAderiagA, SAlvador DE: The Fall of the Spanish A merican Empire, New York 1948. Oviedo y BAÑos, J. DE: Historia de la Conquista y Población de la Provincia de Venesuela, Madrid 1885.

Pereyra, Carlos: Historia de la América española, Madrid 1920-1926, 8 vol.

Simón, Fray Pedro: Noticias historiales de la Conquista de Tierra Firme en las Indias Occidentales, Bogotá 1882. 


\title{
R E S Ư M E N
}

\author{
IGLESIA, CORONA Y CARIBES
}

El descubrimiento del Nuevo Mundo encadenó en España una serie de cruzadas que en su totalidad se llama ,la conquista”. Bajo este término colectivo se unen las palabras sumisión y conversión como conceptos casi idénticos. Los conquistadores, tanto los grandes como los de menos importancia se consideraron no solamente como soldados de los Reyes Católicos y CarLos V, sino también como cruzados, defensores y propagadores de la fe cristiana.

Asimismo se identificaron los poderes seculares y eclesiásticos. Dos bulas papales de 1493 „Inter Caetera” y ,Eximae devotiones” delegaron poderes casi ilimitados a la Corona. Una tercera bula de 1508 completó esta dominación.

A principio los Reyes Católicos, en posesión de estos grandes poderes, aspiraron a proteger sus nuevos súbditos de ultramar, declarándolos en 1503 como libres; sin embargo siguieron en la práctica una línea de conducta propuesta por el jurista palatino PALAcios Rubios de encomendar a la población autóctona de América y esclavizarla por tres instrumentos oficiales: la encomienda, el requerimiento y el repartimiento. Una razón muy fuerte para motivar tal política fué la de la antropofagia, costumbre cruel de la cual fueron acusados en particular los indios caribes, no solamente por autores antiguos como fray PEDRO SIMÓN sino también por autores más modernos como LisAndro AlVARADo.

La situación deplorable en la cual cayeron muy pronto los indios, legalizada por las famosas Leyes de Burgos, inspiró, como es muy natural, a unos hombres nobles y devotos una defensa obstinada y abnegada. Uno de los primeros defensores fué fray Antonio De Montesinos, la „vox clamantis in deserto". El más prominente fué fray BARTOLOMÉ DE LAS CASAS, cuyas tentativas de una conquista pacífica, la de colonizar la Tierra Firme de los caribes, ,la mejor tierra y la más rica que de ella ahora se sabe", frustraron completamente, pero quien a pesar de este fracaso siguió como el más famoso campeón de los naturales en la Corte, el „,Procurador y Protector de los Indios". Contra el fondo de medio siglo de conquista, de odio y menosprecio del indio escribió su tratado: Del único modo de atraer a todos los pueblos a la verdadera religión.

La defensa de los derechos de la población indígena por estos campeones resultó en la promulgación de las Nuevas Leyes. Las vehementes protestas de los conquistadores y de sus descendientes contra estas leyes que anularon el instituto de la encomienda, causaron su pronta liquidación. Sin embargo los parágrafos contra las crueldades de las cuales fueron sujetos los indios encomendados nunca fueron suprimidos, aunque su repetición hasta en el siglo xvin demuestra claramente la verdadera situación de los aborígenes y la actuación de las autoridades que sabotearon la ejecución de los decretos reales con la frase: obedezco mas no cumplo.

Estos decretos se extendieron también a una clase de la población que en el siglo xvirI sobrepasó a los indios y blancos, la de los pardos. Fué esta última clase que uniendo de manera dichosa característicos blancos e indios, no se resignó a esta política de postergación y humillación. De ella salió el movimiento revolucionario que eliminó la identidad de Iglesia y Corona. 